\title{
Placental adaptation to maternal malnutrition
}

\author{
M Carey Satterfield ${ }^{1}$, Ashley K Edwards², Fuller W Bazer ${ }^{1}$, Kathrin A Dunlap ${ }^{1}$, \\ Chelsie B Steinhauser ${ }^{1}$ and Guoyao $\mathrm{Wu}^{1}$ \\ ${ }^{1}$ Department of Animal Science, Texas A\&M University, College Station, Texas, USA and ${ }^{2}$ Dean Lee Research and \\ Extension Center, Louisiana State University, Alexandria, Louisiana, USA
}

Correspondence should be addressed to M C Satterfield; Email: csatterfield@tamu.edu

\begin{abstract}
Maternal malnutrition gives rise to both short- and long-term consequences for the survival and health of the offspring. As the intermediary between mother and fetus, the placenta has the potential to interpret environmental signals, such as nutrient availability, and adapt to support fetal growth and development. While this potential is present, it is clear that at times placental adaptation fails to occur resulting in poor pregnancy outcomes. This review will focus on placental responses to maternal undernutrition related to changes in placental vascularization and hemodynamics and placental nutrient transport systems across species. While much of the available literature describes placental responses that result in poor fetal outcomes, novel models have been developed to utilize the inherent variation in fetal weight when dams are nutrient restricted to identify placental adaptations that result in normal-weight offspring. Detailed analyses of the spectrum of placental responses to maternal malnutrition point to alternations in placental histoarchitectural and vascular development, amino acid and lipid transport mechanisms, and modulation of immune-related factors. Dietary supplementation with selected nutrients, such as arginine, has the potential to improve placental growth and function through a variety of mechanisms including stimulating cell proliferation, protein synthesis, angiogenesis, vasodilation, and gene regulation. Improved understanding of placental responses to environmental cues is necessary to develop diagnostic and intervention strategies to improve pregnancy outcomes.

Reproduction (2021) 162 R73-R83
\end{abstract}

\section{Introduction}

A tremendous body of literature now exists to describe mechanisms whereby the fetus adapts to the intrauterine environment to alter critical physiological set points in preparation for life in the extra-uterine environment (El Hajj et al. 2014). Despite these recent advances, our understanding of the mechanisms employed by the placenta to adapt to maternal and/or fetal cues to optimize its function for the overall well-being of mother and fetus is limited. Despite a biologically diverse array of placental types and shapes, the role of the placenta among eutherian mammals is similar. The placenta mediates the exchange of gases, hormones, nutrients, and waste products between the maternal and fetal circulations (Dunlap et al. 2015). Importantly, placental growth precedes fetal growth, and due to its intermediary role, growth of the placenta is highly correlated with the eventual growth of the fetus (Burton \& Jauniaux 2018). While gross measures of placental growth, such as weight, are predictive of fetal growth, placental transport capacity is a complex biological process. Uteroplacental blood flow, surface area for exchange, transporter availability and activity, and substrate availability are all factors in determining placental transport capacity (Reynolds et al. 2005b,
Burton \& Jauniaux 2018). The consequences of placental impairment or insufficiency are significant. Suboptimal placental function is associated with low birth weight, perinatal morbidity and mortality, and a lifelong predisposition to the development of a myriad of metabolic, cardiovascular, and other disorders (EI Hajj et al. 2014, Cirulli et al. 2020). The purpose of this review is to summarize what is currently known about placental responses to maternal malnutrition, with a particular emphasis on the identification of potentially novel targets or strategies to promote placental growth and function essential for normal development of the fetus and well-being of the offspring.

\section{Malnutrition: a global challenge faced by humans and livestock species alike}

The World Health Organization's definition of malnutrition includes undernutrition (e.g. inadequate intake of amino acids or protein), insufficient vitamin or mineral intake, overweight, and obesity (WHO 2018). According to the 2018 Global Nutrition Report, there are currently 462 million underweight adults, while 1.9 billion adults are either overweight or obese. These nutritional imbalances contribute to the incidence of 
low birth weight, which encompasses roughly one in every ten newborns. The incidence of malnutrition in humans, particularly undernutrition, is a common problem shared among agricultural production systems of mammalian livestock species, such as cattle, swine, sheep, and goats. Importantly, increased losses associated with undernutrition in livestock production systems also contribute to food insecurity for humans in many parts of the world. While overnutrition is a prominent component of the nutritional spectrum, to provide sufficient depth, this review will focus on placental responses to maternal undernutrition with the belief that described studies and approaches likely have relevance across the entirety of the nutritional spectrum.

\section{Nutritional influences on placental vascularization and hemodynamics}

Placentae can be classified both by shape and the number of layers separating the maternal and fetal circulations (Table 1). These structural differences play a key role in the efficiency of nutrient transport and the requisite maternal cardiac output necessary to facilitate adequate exchange between mother and fetus.

Blood flow through the uterus and placenta facilitates the crucial transfer of nutrients, wastes, and gases between the maternal and fetal compartments. Uteroplacental blood flow exponentially increases as pregnancy progresses in humans and livestock, thus correlating with placental function and fetal growth (Reynolds et al. 2006). The absolute rate at which uterine blood flow increases during the second half of pregnancy is different between species, at least 4.5-fold in cattle, 3-fold in sheep, and 2.5-fold in humans and is associated with increases in umbilical flow as well as decreases in umbilical resistance (Reynolds et al. 2006, Dunlap et al. 2015).

The effect of maternal undernutrition on uteroplacental blood flows is surprisingly modest and varies widely among studies, likely due to differences in severity and duration of restriction (Reynolds et al. 2005a). Uterine blood flow was reduced by $17 \%$ when adult sheep were severely undernourished $(60-70 \%$ reduction in the diet compared to controls) during mid-gestation, while there was a $20-33 \%$ reduction in uterine blood flow if the nutritional restriction was applied during late gestation (Chandler et al. 1985, Newnham et al. 1991, Reynolds et al. 2006). Similarly, a 40\% reduction in dietary intake beginning in early gestation results in a reduction in umbilical blood flow and increased arterial indices of resistance (Lemley et al. 2012, Lekatz et al. 2015). Investigators, however, have not observed differences in placental capillary densities in response to the maternal nutrient restriction (Lekatz et al. 2010, Eifert et al. 2015). Consistent with previously described differences in vascular changes between sheep and cattle, a similar $40 \%$ reduction in maternal intake in beef cattle did not affect uterine blood flows even after 110 days of nutrient restriction (Camacho et al. 2014). However, when nutritionally restricted cows were realimented to the control diet, uterine blood flow to the gravid horn increased. A subsequent study found that an earlier realimentation to a control diet following early gestational nutrient restriction increased uterine blood flow above that of both control-fed cows as well as cows experiencing an extended period of nutrient restriction prior to late gestation realimentation (Camacho et al. 2018).

Much of the previously described results were based on Doppler ultrasound, and while this technology has vastly improved in recent decades, its utilization is only suitable for the determination of blood flow measurements in major vessels (Roberts et al. 2018). Indeed, the umbilical artery pulsatility index $(\mathrm{PI})$ is frequently used as an indicator of the hemodynamic properties of the placental villi, such that an increase in PI reflects an increase in microvascular resistance (Acharya et al. 2004). In practice, however, an increase in $\mathrm{Pl}$ only becomes detectable when $\sim 60 \%$ of terminal vascular branches are disrupted (Thompson and Trudinger 1990), leading to significant concerns regarding the sensitivity of available technologies to detect less severe incidences of placental dysfunction. Roberts et al. (2016) recently established methodologies to utilize contrast-enhanced ultrasound to assess microvascular perfusion in the intervillous space

Table 1 Characteristics of the placenta across species.

\begin{tabular}{|c|c|c|c|c|c|}
\hline Species & Placental type & Placental shape & Placental layers & Length of gestation (days) & $\begin{array}{l}\text { Timing of peak placental mass } \\
\text { (proportion of pregnancy) }\end{array}$ \\
\hline Pig & Epitheliochorial & Diffuse & 6 & 114 & Day $100(0.87)^{1}$ \\
\hline Sheep & Synepitheliochorial & Cotyledonary & $5-6$ & 147 & Day $90(0.61)^{2}$ \\
\hline Cow & Synepitheliochorial & Cotyledonary & $5-6$ & 283 & Day $283(1.00)^{3}$ \\
\hline Human & Hemochorial & Mono-discoid & 3 & 268 & Day $268(1.00)^{4}$ \\
\hline Baboon & Hemochorial & Mono-discoid & 3 & 184 & NA \\
\hline Rhesus monkey & Hemochorial & Bi-discoid & 3 & 164 & Day $164(1.00)^{5}$ \\
\hline Mouse & Hemochorial & Mono-discoid & 3 & 20 & Day $20(1.00)^{6}$ \\
\hline Rat & Hemochorial & Mono-discoid & 3 & 22 & Day $19(0.86)^{7}$ \\
\hline
\end{tabular}

${ }^{1}$ Michael et al. (1983); ${ }^{2}$ Alexander (1964); ${ }^{3}$ Laven \& Peters (2001); ${ }^{4}$ Molteni et al (1978); ${ }^{5}$ van Wagenen \& Catchpole (1965); ${ }^{6}$ Kulandavelu et al. (2006); ${ }^{7}$ Furukawa et al. (2011). 
of human and non-human primate placentae. These methods were then employed to assess the effect of a $50 \%$ protein restriction, for the entirety of pregnancy, in the rhesus macaque. Ultrasound assessment of placental hemodynamics found that umbilical artery, but not uterine artery $\mathrm{Pl}$, was elevated in protein-restricted primates in late gestation. The increase in umbilical artery $\mathrm{PI}$ was associated with a decrease in placental perfusion (Roberts et al. 2018). It should be noted that the $50 \%$ protein restriction for the entirety of gestation is a substantial nutritional insult, as evidenced by a $50 \%$ rate of pregnancy loss in restricted monkeys (Roberts et al. 2018). Additional studies are needed to ascertain the sensitivity of the contrast-enhanced ultrasonography in less severe cases of maternal malnutrition that may lead to poor pregnancy outcomes.

\section{Influence of maternal nutrition on nutrient transporter expression and activity}

While uteroplacental blood flows are critical for the movement of factors involved in fetal growth, placental transport capacity for many substances is mediated at the cellular level via complex transporter gene families known as the solute carrier (SLC) family of molecules (Broer 2008, Satterfield et al. 2010b). Indeed, the presence and activity of specific transporters is likely the rate-limiting factor in the transit of glucose and amino acids in uteroplacental cells. In mice, a modest $20 \%$ reduction in the diet compared to controls, beginning at day 3 of gestation, resulted in decreased placental, but not fetal weight at day 16 , although there was a decrease in both fetal and placental weights at day 19 (Coan et al. 2010). This corresponded to reduced placental mRNA expression of glucose transporter SLC2A1 at day 16 , but at day 19 of gestation, both SLC2A1 and sodium-dependent amino acid transporter SLC38A2 had increased gene expression (Coan et al. 2010). Amino acid transport systems are down-regulated in the placenta in early gestation, prior to the start of fetal growth restriction, in rats exposed to a maternal dietary protein restriction for the duration of pregnancy (Malandro et al. 1996, Jansson et al. 2006). The reduced dietary protein intake was associated with lower fetal and maternal serum concentrations of amino acids as well as reduced fetal and placental weights at day 20 (Malandro et al. 1996). The activity of cationic amino acid transporters was reduced, as was the activity of anionic sodium-dependent transporters in placentae of rats on a low protein diet, but the activity of anionic sodium-independent transporters was unaffected (Malandro et al. 1996).

In a second study, rats on a low protein diet, at day 21 of pregnancy had down-regulated placental protein and mRNA levels of transporters in the sodium-dependent system A (SLC38A2 and SLC38A4), which have an affinity for neutral amino acids, but neutral amino acid transporters in the sodium-dependent system ASC were not affected (Jansson et al. 2006). The system A transporter family has been hypothesized to be essential for fetal growth in rats (Cramer et al. 2002). Indeed, administration of 2-(methylamino)isobutyric acid between days 7 and 20 of gestation, to inhibit the system A transporter family, resulted in decreased fetal weight via a mechanism that has not been fully elucidated (Cramer et al. 2002).

Additional evidence regarding the influence of dietary intake on the expression of placental amino acid transporters has been found in studies with the baboon. Maternal total caloric nutrient restriction from days 30 to 165 of gestation reduced fetal circulation concentrations of select amino acids and was associated with alterations in the nutrient-sensing, mammalian target of rapamycin (MTOR) signaling pathway (Kavitha et al. 2014). A subsequent study detailed reductions in the placental microvillous system A plasma membrane vesicle activity, culminating in reduced placental transport of leucine (Pantham et al. 2015). Similar to previous work in the rat, downregulation of placental amino acid transport precedes the development of fetal growth restriction in the nutrient-restricted non-human primate (Pantham et al. 2016).

While several studies have identified alterations in placental transport of amino acids in response to maternal nutrient restriction in sheep (Kwon et al. 2004, Satterfield et al. 2010a), the influence of nutrient restriction on the expression of placental amino acid transporter genes is not well known. Despite the limited number of transporters that have been investigated, expression of SLC38A2 mRNA was reduced in placentomes from nutrient-restricted sheep at mid-gestation, similar to that found for protein-restricted rats (Dunlap et al. 2015). Data regarding the effect of maternal malnutrition on the placental expression of amino acid and glucose transporter genes are similarly lacking in the cow. Available studies with cattle investigated the effect of maternal nutrient restriction only to day 50 of pregnancy and found no difference in expression of glucose, cationic, neutral, or acidic amino acid transporters in the endometrium after implantation (Crouse et al. 2017, Greseth et al. 2017). This was despite modest differences in concentrations of amino acids in the amniotic and allantoic fluid between control-fed and nutrientrestricted cattle (Crouse et al. 2019). It should be noted that analysis of expression of amino acid transporters in the placentomes was not undertaken. Given that the placentome is the primary site of hematotrophic support during pregnancy, the differences in amounts of amino acids in allantoic and amniotic fluids may reflect changes in the developing placentomes. 


\section{Exploring population variance as a means to understand placental responses to maternal malnutrition}

Heterogeneity of a population is a persistent challenge in the conduct of research on factors affecting outcomes of pregnancy. As heterogeneity increases, sample sizes must be increased to provide sufficient statistical power to identify significant differences. Compared to humans and large animal models, laboratory rodent models exhibit less genetic variation that contributes, in part, to their adoption as a valuable research tool despite significant differences in fetal physiology. In the course of our research with the pregnant sheep model, we consistently observed a subset of pregnant sheep that, despite long-term maternal nutrient restriction at 50\% of NRC requirements, supported rates of fetal growth similar to those for well-fed control sheep (Edwards et al. 2020b, Sandoval et al. 2020). We have initiated a line of investigation focusing on each end of the spectrum of responses to maternal nutrient restriction as a means to identify critical factors regulating placental growth and function.

Results of our recent research identified a quantifiable reduction in caruncular crypt density coupled with limited contact and juxtaposition of the maternal caruncle and fetal cotyledonary tissues in nutrient-restricted (NR) sheep having growth-restricted fetuses compared to NR sheep having fetuses of normal weight (Edwards et al. $2020 b$ ). At the molecular level, we observed reductions in the expression of the amino acid transporters $S L C 7 A 6$, $S L C 7 A 7$, and SLC38A2 in the placentomes of NR sheep having growth-restricted fetuses compared to NR sheep having fetuses of normal weight. Importantly, these changes in placental histoarchitecture and amino acid transporter expression were associated with reduced amino acid availability in the fetal circulation, even when there were no differences in amino acid concentrations in maternal circulation. One additional observation of interest in this study was that the expression of the amino acid transporter SLC7A2 in the placentome was reduced in all NR animals irrespective of fetal growth rate. While clearly, these data suggest that SLC7A2 expression is highly sensitive to maternal nutritional intake, its expression does not appear to correlate with actual rates of fetal growth.

In the same cohort of animals, an assessment of gene expression for known angiogenic factors at day 125 of gestation found that VEGFA mRNA expression in the placentome was upregulated in NR sheep having normal-weight fetuses compared to NR sheep having growth-restricted fetuses as well as well-fed controls (Fig. 1). Reynolds et al. (2005a) observed no difference in VEGF mRNA expression in placentomes from NR vs well-fed sheep at either day 90 or day 130 of gestation but did detect decreases in the VEGF receptors (FLT1 and $K D R$ ) in NR sheep on day 130. The apparent

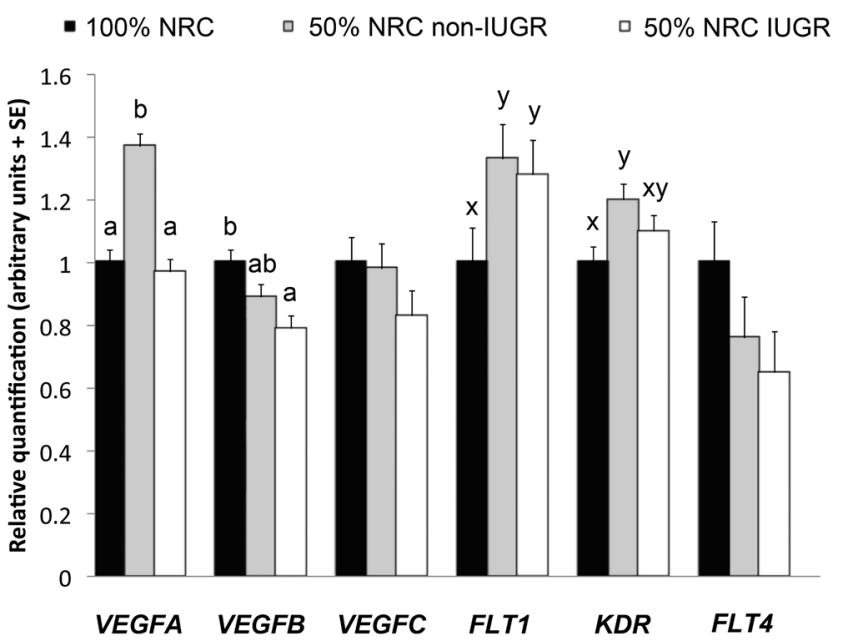

Figure 1 Expression of mRNAs for angiogenic factors in placentomes at day 125 of gestation was determined by qPCR as previously described (Edwards et al. 2020b). The following primers were used: VEGFA, F-GCCCACTGAGGAGTTCAACATC R-GCTGGCTTTGGT GAGGTTTG; VEGFB, F-TCCAAGGCTGCCATCCA R-GACСССTCT TGGTCTCCTCAT; VEGFC, F-CCAGGCTGCAAACAAGACTTG R-CATCTGCAGACGTGGTTATTCC; FLT1 F- TGGATTTCA GGTGAGCTTGGA R-TCACCGTGCAAGACAGCTTC; KDR, FGCTTGGCCCGGGATATTTA R-GGCGAGCATCTCCTTTTCTG; FLT4 F- GAGCATCGCGCCCTGAT R-CACGTTGAGGTGGTTACCAATG. Singleton fetuses from the ewes fed $50 \%$ NRC diets from days 35 to 125 of pregnancy were categorized based on fetal weight at day 125 into NR non-IUGR (top quartile of fetuses) and NR IUGR (bottom quartile of fetuses), while fetuses from ewes fed 100\% NRC diets were controls. Expression of VEGFA mRNA was greater $(P<0.05)$ in placentomes from NR non-IUGR fetuses than either control or NR IUGR fetuses. VEGFB mRNA expression was lower in NR IUGR compared to control placentomes $(P<0.05)$. Expression of $F L T 1$ mRNA in placentomes from control ewes tended to be lower $(P<0.10)$ than for NR ewes. Expression of $K D R$ mRNA tended $(P<0.10)$ to be lower in control placentomes vs NR non-IUGR placentomes.

compensatory upregulation of VEGFA mRNA in a subset of NR sheep described in the former study highlights the value of evaluating population variance for the discovery of novel factors that may promote placental angiogenesis to increase placental nutrient exchange. Of note, Reynolds et al. (2005a) found that VECF mRNA expression within the placentome was most highly correlated with capillary area density, capillary number density, and capillary surface density of the fetal cotyledon, but not caruncle. Taken together, this suggests that the upregulation of VEGFA in placentomes from NR sheep having normal-weight fetuses is a mechanism whereby conceptuses increase placental nutrient exchange.

An exploratory analysis of placental gene expression within this experimental paradigm identified 103 differentially expressed genes in placentomes from NR ewes having either normal or growth-restricted fetuses on day 125 of gestation (Edwards et al. 2020a). Pathway enrichment analyses, not surprisingly, identified nutrient 
and amino acid transport as two of the top ten most highly enriched gene clusters among genes that were upregulated in NR ewes having growth-restricted fetuses. Interestingly, five of the remaining eight most highly enriched clusters were associated with immune system activation. Similar findings were observed in the nutritionally restricted pregnant mouse model where genes associated with immunologically mediated processes such as vascular inflammation, ER stress, and autophagy were differentially expressed in the placenta in response to the maternal nutrient restriction (Chu et al. 2016). Collectively, results suggest that mechanisms to temper inappropriate immunologically related responses to nutritional stress may be beneficial in preventing fetal growth restriction.

One of the challenges hindering our understanding of placental adaptation to a given insult is that the placenta develops prior to the fetus, therefore, it is difficult to conclusively illustrate that an early gestation placental phenotype gives rise to a late gestation fetal phenotype. Ultrasound-based approaches fail to identify the earliest changes in placental development. Placental biopsies provide minimal tissue for study and may not be a representative sample of both fetal and maternal tissues. In an attempt to overcome these challenges, we developed a surgical method whereby a single placentome is removed from pregnant sheep during early gestation without compromising the pregnancy (Lambo et al. 2020). This allows the pregnancy to progress to a later point in gestation for retrospective analyses of how the developing placenta responds to an insult (i.e. nutrient restriction) and then a second assessment of the maximally functioning placentome in late gestation, along with a fetal phenotype, in the same sheep.

Utilizing this surgical approach, we recently found that concentrations of triglycerides and bile acids in allantoic fluid of NR ewes on day 70 of gestation are negatively correlated with fetal weight in late gestation (Steinhauser et al. 2021). The accumulation of triglycerides and bile acids in the allantoic fluid of growth-restricted pregnancies likely highlights a reduced ability of the allantoic epithelium to transport these molecules out of the allantoic fluid reservoir for utilization by the fetus and removal of waste products, respectively. Indeed, growth-restricted fetuses in our study had lower concentrations of triglycerides and elevated bile acids in the fetal circulation. We further found that protein abundance of the fatty acid transporter protein SLC27A6 (also known as FATP6) in the mid-gestation placentome was decreased in NR ewes having growth-restricted fetuses compared to those having normal-weight fetuses. Interestingly, while the expression of other members of the fatty acid transporter family are modest in mid-gestation and increase to term, expression of SLC27A6 is abundantly expressed in midgestation, during placental development, and declines dramatically to term. Thus, the potential importance of SLC27A6 as an early mediator of placental growth would likely have been overlooked if only placental samples from late gestation were evaluated. In the baboon, a 30\% maternal nutrient restriction resulted in increased expression of both SLC27A2 and SLC27A6 in late gestation (Chassen et al. 2020). Investigators hypothesized that this upregulation was a compensatory mechanism by which the nutritionally challenged fetus attempts to increase its nutritional supply.

Observations of differential responses to maternal nutrient restriction have been observed in other species. Long et al. (2009) observed that only a subset of cows experienced IUGR at mid-gestation in response to maternal nutrient restriction and that IUGR was associated with a reduction in cotyledonary weights and surface area of placentomes compared to NR cows having calves with normal weights. These observations are further supported by research comparing the Baggs sheep vs University of Wyoming (UW) sheep. The Baggs sheep and University of Wyoming sheep arose from a similar genetic base; however, Baggs sheep were selected for survival in areas of limited nutrient availability, while UW sheep were raised in a more temperate environment. Interestingly, when nutritionally challenged at an identical level, UW sheep gave rise to IUGR offspring, while Baggs sheep did not (Jobgen et al. 2008). Amino acid analyses of blood revealed that Baggs sheep had greater placental transport activity compared to that for diet-matched UW sheep.

Even in relatively homogeneous populations of animals, placental adaptation to nutritional deficits has been observed. In WT mice with normal fetuses, the system A amino acid transporter system is adaptively upregulated in the lightest vs the heaviest placentae within a litter (Mclntyre et al. 2019). While the lightest placentae were $23 \%$ lighter than the heaviest, there was a $154 \%$ increase in the glutamine transporter in placentae resulting in only a $5 \%$ difference in fetal weights at day 18.5. A subsequent study comparing the WT C57BL/6] and placenta-specific insulin-like growth factor 2 (Igf2) (P0) knockout mouse, a mutation known to induce fetal growth restriction, found that placentae from mutant mice initially upregulated system A transporter capacity, but by late gestation, this adaptation was insufficient to rescue fetal growth (Mclntyre et al. 2019). Those results support previous findings for placentae from human babies across the normal spectrum of birth weights where system A transporter activity per microgram microvillous membrane protein was greatest in the lighter babies (Godfrey et al. 1998). Those researchers previously reported a decrease in system A transporter activity in placentae of growth-restricted babies and have suggested that they failed to adaptively increase system A transporter activity under conditions that result in fetal growth restriction (Sibley et al. 2010). 


\section{Nutritional strategies to improve placental growth and function}

Amino acids are the central building blocks for protein synthesis required for normal fetal growth. However, their roles in promoting fetal growth and development go far beyond simply serving as a substrate for fetal protein synthesis. Arginine, a conditionally essential amino acid during pregnancy, not only serves as an important amino acid for protein synthesis but can also be catabolized into bioactive molecules of critical importance (Fig. 2). Indeed, arginine catabolism yields nitric oxide, ornithine, polyamines, creatine, proline, and glutamate (Wu et al. 2009). Nitric oxide serves as a key regulator of placental angiogenesis and vasodilation. Polyamines (polycationic molecules synthesized from the amino acid arginine (via two potential metabolic pathways)) regulate gene expression, signal transduction, ion channel function, DNA and protein synthesis, and angiogenesis, as well as proliferation, differentiation, and functions of cells (Lenis et al. 2017). To date, there have been no studies investigating the efficacy of polyamine supplementation as a means to stimulate placental function; however, a growing body of evidence supports the need for this research.

Inhibition of ornithine decarboxylase (ODC1), a key enzyme in polyamine synthesis, using alphadifluormethylornithine during mid-pregnancy in mice results in embryonic growth arrest and impaired development of the yolk sac and placentae (LopezGarcia et al. 2008), while null mutation of Odc1 results in early embryonic lethality (Pendeville et al. 2001). In rats, inhibition of ODC1 activity results in intrauterine growth restriction as well as a reduction in placental weight and DNA content (Ishida et al. 2002). Further, pharmacological inhibition of ODC1 has been shown to decrease microvascular sprouting of human umbilical vein endothelial cells, in vitro (Kucharzewska et al. 2010). Sheep conceptuses fail to develop when the translation of both $O D C 1$ and $A D C$ mRNAs were knocked down to prevent the synthesis of polyamines (Lenis et al. 2018). Finally, increased amounts of polyamines and their amino acid precursors were found in the circulation of NR pregnant sheep that had normal-weight placentae and fetuses as compared to those that had small placentae and growth-restricted fetuses (Edwards et al. 2020b). These data highlight a positive association between increased polyamine availability and placental and fetal growth in the nutritionally challenged sheep.

The efficacy for maternal arginine supplementation to prevent fetal growth restriction has been varied and likely depends on the timing, dose, chemical form, and duration of supplementation. Dietary supplementation with $1 \%$ arginine- $\mathrm{HCl}$ to gilts between days 30 and 114 of gestation increases litter birth weight of live-born piglets (Mateo et al. 2007). Similarly, dietary supplementation with $0.83 \%$ arginine to gilts between days 14 and 30 of gestation enhances placental angiogenesis (Wu et al. 2017), placental growth, and the number of live embryos (Li et al. 2014). In nutritionally restricted sheep, maternal arginine supplementation from day 60 of gestation to term increased the birth weights of lambs by $21 \%$ (Lassala et al. 2010). Dietary supplementation with either L-arginine or N-carbamylglutamate, (a metabolically stable activator of intestinal synthesis of citrulline and arginine from glutamine, glutamate, and proline (Wu et al. 2004), to NR sheep from days 35 to 110 of gestation was successful in increasing fetal weights at necropsy compared to NR sheep receiving no supplement (Zhang et al. 2016). In contrast, supplementation from days 100 to 125 of gestation did not increase fetal weights at necropsy on day 125; however, brown adipose tissue and pancreatic mass were both increased in response to arginine supplementation (Satterfield et al. 2013). Thus, arginine supplementation may reduce cold-induced perinatal mortality of ruminant livestock species (McKnight et al. 2020) and may ameliorate some of the negative aspects of metabolic programming in a wide array of animal species following maternal malnutrition.

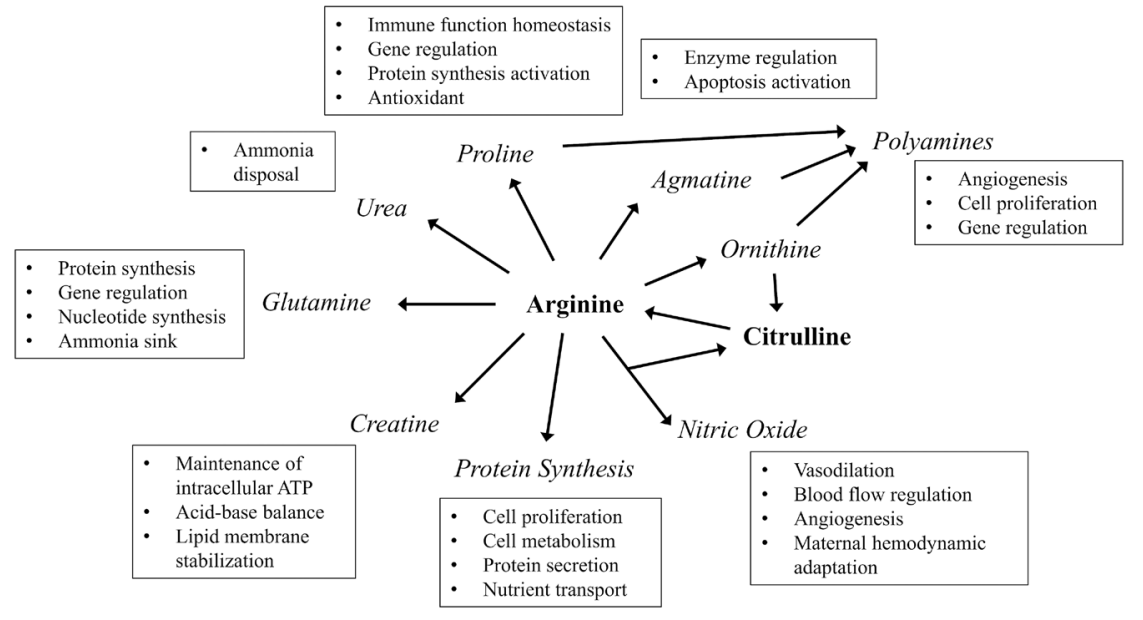

Figure 2 Roles of arginine and associated molecules in placental function. Arginine is a precursor to proline, agmatine, ornithine, citrulline, nitric oxide, creatine, glutamine, and urea but can also be synthesized from citrulline, therefore, the roles of citrulline are associated with downstream actions of arginine. Arginine is also a potent stimulator of protein synthesis. This figure is compiled from these sources (Wu et al. 2009, 2011, Dickinson et al. 2014, Laube \& Bernstein 2017, Hsu \& Tain 2019). 
In human pregnancy, L-arginine supplementation has mostly been investigated as a means to combat gestational hypertension or improve placental function in pre-eclampsia. Results of those studies suggest that L-arginine supplementation improves maternal diastolic blood pressure and extends the length of gestation (Facchinetti et al. 2007, Neri et al. 2010). There was a varied response in birth outcome most typically associated with duration of supplementation or severity of fetal growth restriction at the initiation of supplementation. When hypertensive mothers were administered $20 \mathrm{~g}$ /day of L-arginine for 5 days after a preeclampsia diagnosis made between weeks 20 and 36 of gestation, there was no effect on birth weight (Facchinetti et al. 2007) nor was there an improved birth weight when L-arginine was administered at $12 \mathrm{~g}$ /day for only 5 days between weeks 28 and 36 (Staff et al. 2004). In contrast, the majority of studies reporting a significant improvement in birth outcome used a prolonged, low-dose strategy for arginine supplementation where L-arginine was administered at 3-5 g/day from approximately week 20 of pregnancy until delivery (Vadillo-Ortega et al. 2011, Camarena Pulido et al. 2016). As most of these studies have been performed in women considered high risk for, or diagnosed with, gestational hypertension, and since supplementation commenced at least halfway through pregnancy, the question still remains as to the benefits of L-arginine supplementation during placental development in the first half of pregnancy. Of specific interest would be whether early administration of L-arginine would occlude the onset of hypertension, or, at a minimum, continue to temper the severity as is observed with administration later in pregnancy. Additionally, the use of L-arginine or L-citrulline supplementation in low resource settings that likely experience significant maternal malnutrition has not been undertaken (Weckman et al. 2019).

While arginine supplementation has shown potential to increase fetal growth in humans, sheep, and rats, there are concerns about the efficacy of long-term supplementation due to potential effects on acidbase balance or chronic provision of chloride when administered as an $\mathrm{HCl}$ salt (Lassala et al. 2009). Further, cells and tissues which have high arginase activity contribute to the relatively short biological halflife of L-arginine in mammals, and intestinal arginase, specifically, inhibits the availability of orally provided supplemental L-arginine in humans (Castillo et al. 1993, Wu et al. 2007). L-citrulline is a neutral amino acid and is an effective precursor for arginine synthesis in humans, pigs, ruminants, and rodents (Gilbreath et al. 2020). In pregnant sheep, the half-life of L-citrulline is twice that of L-arginine and was more effective in sustaining high concentrations of arginine in both the maternal and fetal circulations, as well as ornithine in the fetal circulation (Lassala et al. 2009). Based on our recent discovery that extracellular citrulline is not degraded by the ruminal microbes of adult ruminants (Gilbreath et al. 2020), dietary supplementation with unencapsulated citrulline may be an effective means to improve placental and fetal growth in cattle, sheep, and goats. In rats, both L-arginine and L-citrulline supplementation to pregnant rats fed a low protein diet increased fetal weight near term (Bourdon et al. 2016). However, L-citrulline supplementation increased the fetal/placental weight ratio (an indicator of placental efficiency) more than L-arginine supplementation. While L-arginine supplementation was associated with an increase in ornithine in maternal plasma, L-citrulline supplementation further increased concentrations of ornithine. This is consistent with a longer half-life of citrulline than arginine in gestating dams to sustain an elevated concentration of arginine for the production of ornithine by arginase (Wu et al. 2007). While L-arginine has been shown to have beneficial effects during pregnancy in multiple species, the supplemental use of L-citrulline moving forward certainly has merit for consideration in both humans and livestock species.

Leucine has also received consideration as a nutritional strategy to improve fetal growth as it has been shown to increase protein synthesis, resulting in increased skeletal muscle mass, as well as promote fetal pancreatic development and insulin secretion in fetal pigs and sheep (Wang et al. 2018, Boehmer et al. 2020). In the sheep study, leucine was infused into the fetal circulation in late gestation and potential impacts on placental function were not investigated (Boehmer et al. 2020). Leucine has been shown to activate the mechanistic target of rapamycin (mTOR) signaling pathway in trophectoderm cells in vitro, from both pigs and humans, and may play a role in the nutrient-sensing actions of the mTOR pathway and its effects on placental development (Roos et al. 2007, Kim et al. 2013).

Lipid-based supplements including omega-3 longchain polyunsaturated fatty acids (PUFA) or mixed doses of essential fatty acids have demonstrated moderate improvements in pregnancy outcomes in women as well as the growth of the children in low nutrition environments (Adu-Afarwuah et al. 2015, 2016, Saccone et al. 2015, Middleton et al. 2018). In adequately fed sheep, supplementation of omega-3 PUFA during pregnancy had no effect on placental and fetal weights (Nickles et al. 2019, Rosa Velazquez et al. 2020). Further research is necessary to determine if omega-3 PUFA supplementation would enhance placental and fetal growth in a nutrient-restricted cohort.

\section{Conclusions}

The placenta serves as the critical intermediary between the maternal and fetal environments. Despite its transient role as the mediator of the exchange of nutrients, gases, and waste between mother and fetus, the capacity of the placenta to adapt to environmental stresses has 
a lifelong impact on the health and well-being of the offspring. Maternal undernutrition is a common environmental stressor associated with increased risk for a myriad of postnatal health disorders such as cardiovascular disease and metabolic syndrome. A renewed focus on the scientific investigation of adaptive biological responses has identified compensatory changes in amino acid and lipid transport mechanisms, increased expression of angiogenic factors, and differential activation of immune-related factors as potential mediators of improved placental function, and fetal outcomes, in the undernourished dam. Further, new methodological approaches have the potential to identify early changes in placental development that are truly causative regulators of fetal growth. These observations and methodological advances are critical first steps toward the development of nutraceutical and therapeutic strategies, such as selected amino acid supplementation, to improve pregnancy outcomes in the face of limited nutrient availability.

\section{Declaration of interest}

The authors declare that there is no conflict of interest that could be perceived as prejudicing the impartiality of this review.

\section{Funding}

This work was supported by Eunice Kennedy Shriver National Institute of Child Health and Human Development grant no. 1R01HD080658-01A1 (M C S) from the National Institutes of Health.

\section{Author contribution statement}

M C S was responsible for the original manuscript. A K E performed experiments and collected data. FW B, KA D, CB S, and G W provided crucial intellectual input into the design, writing, and editing of the manuscript.

\section{References}

Acharya G, Erkinaro T, Makikallio K, Lappalainen T \& Rasanen J 2004 Relationships among Doppler-derived umbilical artery absolute velocities, cardiac function, and placental volume blood flow and resistance in fetal sheep. American Journal of Physiology: Heart and Circulatory Physiology $286 \mathrm{H} 1266-\mathrm{H} 1272$. (https://doi.org/10.1152/ ajpheart.00523.2003)

Adu-Afarwuah S, Lartey A, Okronipa H, Ashorn P, Zeilani M, Peerson JM, Arimond M, Vosti S \& Dewey KG 2015 Lipid-based nutrient supplement increases the birth size of infants of primiparous women in Ghana. American Journal of Clinical Nutrition 101 835-846. (https://doi. org/10.3945/ajcn.114.091546)

Adu-Afarwuah S, Lartey A, Okronipa H, Ashorn P, Peerson JM, Arimond M, Ashorn U, Zeilani M, Vosti S \& Dewey KG 2016 Small-quantity, lipidbased nutrient supplements provided to women during pregnancy and 6 mo postpartum and to their infants from 6 mo of age increase the mean attained length of 18-mo-old children in semi-urban Ghana: a randomized controlled trial. American Journal of Clinical Nutrition 104 797-808. (https://doi.org/10.3945/ajcn.116.134692)

Alexander G 1964 Studies on the placenta of the sheep (Ovis aries): Placental size. Journal of Reproduction and Fertility 7 289-305. (https:// doi.org/10.1530/jrf.0.0070289)

Boehmer BH, Baker PR, Brown LD, Wesolowski SR \& Rozance PJ 2020 Leucine acutely potentiates glucose-stimulated insulin secretion in fetal sheep. Journal of Endocrinology 247 115-126. (https://doi.org/10.1530/ JOE-20-0243)

Bourdon A, Parnet P, Nowak C, Tran NT, Winer N \& Darmaun D 2016 L-citrulline supplementation enhances fetal growth and protein synthesis in rats with intrauterine growth restriction. Journal of Nutrition $\mathbf{1 4 6}$ 532-541. (https://doi.org/10.3945/jn.115.221267)

Broer S 2008 Amino acid transport across mammalian intestinal and renal epithelia. Physiological Reviews 88 249-286. (https://doi.org/10.1152/ physrev.00018.2006)

Burton GJ \& Jauniaux E 2018 Pathophysiology of placental-derived fetal growth restriction. American Journal of Obstetrics and Gynecology 218 S745-S761. (https://doi.org/10.1016/j.ajog.2017.11.577)

Camacho LE, Lemley CO, Prezotto LD, Bauer ML, Freetly HC, Swanson KC \& Vonnahme KA 2014 Effects of maternal nutrient restriction followed by realimentation during midgestation on uterine blood flow in beef cows. Theriogenology $\mathbf{8 1} 1248-1243 . \quad$ (https://doi.org/10.1016/j. theriogenology.2014.02.006)

Camacho LE, Lemley CO, Dorsam ST, Swanson KC \& Vonnahme KA 2018 Effects of maternal nutrient restriction followed by realimentation during early and mid-gestation in beef cows II: placental development, umbilical blood flow, and uterine blood flow responses to diet alterations. Theriogenology 116 1-11. (https://doi.org/10.1016/j. theriogenology.2018.04.013)

Camarena Pulido EE, García Benavides L, Panduro Barón JG, Pascoe Gonzalez S, Madrigal Saray AJ, García Padilla FE \& Totsuka Sutto SE 2016 Efficacy of L-arginine for preventing preeclampsia in high-risk pregnancies: a double-blind, randomized, clinical trial. Hypertension in Pregnancy 35 217-225. (https://doi.org/10.3109/10641955.2015.11 37586)

Castillo L, Chapman TE, Sanchez M, Yu YM, Burke JF, Ajami AM, Vogt J \& Young VR 1993 Plasma arginine and citrulline kinetics in adults given adequate and arginine-free diets. PNAS 90 7749-7753. (https://doi. org/10.1073/pnas.90.16.7749)

Chandler KD, Leury BJ, Bird AR \& Bell AW 1985 Effects of undernutrition and exercise during late pregnancy on uterine, fetal and uteroplacental metabolism in the ewe. British Journal of Nutrition 53 625-635. (https:// doi.org/10.1079/bjn19850072)

Chassen SS, Ferchaud-Roucher V, Palmer C, Li C, Jansson T, Nathanielsz PW \& Powell TL 2020 Placental fatty acid transport across late gestation in a baboon model of intrauterine growth restriction. Journal of Physiology 598 2469-2489. (https://doi.org/10.1113/JP279398)

Chu A, Thamotharan S, Ganguly A, Wadehra M, Pellegrini M \& Devaskar SU 2016 Gestational food restriction decreases placental interleukin-10 expression and markers of autophagy and endoplasmic reticulum stress in murine intrauterine growth restriction. Nutrition Research 36 1055-1067. (https://doi.org/10.1016/j.nutres.2016.08.001)

Cirulli F, Musillo C \& Berry A 2020 Maternal obesity as a risk factor for brain development and mental health in the offspring. Neuroscience $\mathbf{4 4 7}$ 122-135. (https://doi.org/10.1016/j.neuroscience.2020.01.023)

Coan PM, Vaughan OR, Sekita Y, Finn SL, Burton GJ, Constancia M \& Fowden AL 2010 Adaptations in placental phenotype support fetal growth during undernutrition of pregnant mice. Journal of Physiology 588 527-538. (https://doi.org/10.1113/jphysiol.2009.181214)

Cramer S, Beveridge M, Kilberg M \& Novak D 2002 Physiological importance of system A-mediated amino acid transport to rat fetal development. American Journal of Physiology: Cell Physiology 282 C153-C160. (https://doi.org/10.1152/ajpcell.2002.282.1.C153)

Crouse MS, McLean KJ, Greseth NP, Crosswhite MR, Pereira NN, Ward AK, Reynolds LP, Dahlen CR, Neville BW, Borowicz PP et al. 2017 Maternal nutrition and stage of early pregnancy in beef heifers: impacts on expression of glucose, fructose, and cationic amino acid transporters in utero-placental tissues. Journal of Animal Science 95 5563-5572. (https://doi.org/10.2527/jas2017.1983)

Crouse MS, Greseth NP, McLean KJ, Crosswhite MR, Pereira NN, Ward AK, Reynolds LP, Dahlen CR, Neville BW, Borowicz PP et al. 2019 Maternal 
nutrition and stage of early pregnancy in beef heifers: impacts on hexose and AA concentrations in maternal and fetal fluids1. Journal of Animal Science 97 1296-1316. (https://doi.org/10.1093/jas/skz013)

Dickinson H, Ellery S, Ireland Z, LaRosa D, Snow R \& Walker DW 2014 Creatine supplementation during pregnancy: summary of experimental studies suggesting a treatment to improve fetal and neonatal morbidity and reduce mortality in high-risk human pregnancy. BMC Pregnancy and Childbirth 14 150-150. (https://doi.org/10.1186/1471-2393-14150)

Dunlap KA, Brown JD, Keith AB \& Satterfield MC 2015 Factors controlling nutrient availability to the developing fetus in ruminants. Journal of Animal Science and Biotechnology 6 16. (https://doi.org/10.1186/ s40104-015-0012-5)

Edwards AK, Dunlap KA, Spencer TE \& Satterfield MC 2020a Identification of pathways associated with placental adaptation to maternal nutrient restriction in sheep. Genes 11 1031. (https://doi.org/10.3390/ genes11091031)

Edwards AK, McKnight SM, Askelson K, McKnight JR, Dunlap KA \& Satterfield MC 2020b Adaptive responses to maternal nutrient restriction alter placental transport in ewes. Placenta 96 1-9. (https://doi. org/10.1016/j.placenta.2020.05.002)

Eifert AW, Wilson ME, Vonnahme KA, Camacho LE, Borowicz PP, Redmer DA, Romero S, Dorsam S, Haring J \& Lemley CO 2015 Effect of melatonin or maternal nutrient restriction on vascularity and cell proliferation in the ovine placenta. Animal Reproduction Science 153 13-21. (https://doi.org/10.1016/j.anireprosci.2014.11.022)

El Hajj N, Schneider E, Lehnen H \& Haaf T 2014 Epigenetics and lifelong consequences of an adverse nutritional and diabetic intrauterine environment. Reproduction 148 R111-R120. (https://doi.org/10.1530/ REP-14-0334)

Facchinetti F, Saade GR, Neri I, Pizzi C, Longo M \& Volpe A 2007 L-arginine supplementation in patients with gestational hypertension: a pilot study. Hypertension in Pregnancy 26 121-130. (https://doi. org/10.1080/10641950601147994)

Furukawa S, Hayashi S, Usuda K, Abe M, Hagio S \& Ogawa I 2011 Toxicological pathology in the rat placenta. Journal of Toxicologic Pathology 24 95-111. (https://doi.org/10.1293/tox.24.95)

Gilbreath KR, Nawaratna GI, Wickersham TA, Satterfield MC, Bazer FW \& Wu G 2020 Metabolic studies reveal that ruminal microbes of adult steers do not degrade rumen-protected or unprotected L-citrulline. Journal of Animal Science 98 skz370. (https://doi.org/10.1093/jas/ skz370)

Godfrey KM, Matthews N, Glazier J, Jackson A, Wilman C \& Sibley CP 1998 Neutral amino acid uptake by the microvillous plasma membrane of the human placenta is inversely related to fetal size at birth in normal pregnancy. Journal of Clinical Endocrinology and Metabolism 83 3320-3326. (https://doi.org/10.1210/jcem.83.9.5132)

Greseth NP, Crouse MS, McLean KJ, Crosswhite MR, Pereira NN, Dahlen CR, Borowicz PP, Reynolds LP, Ward AK, Neville BW et al. 2017 The effects of maternal nutrition on the messenger ribonucleic acid expression of neutral and acidic amino acid transporters in bovine uteroplacental tissues from day sixteen to fifty of gestation. Journal of Animal Science 95 4668-4676. (https://doi.org/10.2527/jas2017.1713)

Hsu CN \& Tain YL 2019 Impact of arginine nutrition and metabolism during pregnancy on offspring outcomes. Nutrients 11 1452. (https:// doi.org/10.3390/nu11071452)

Ishida M, Hiramatsu Y, Masuyama H, Mizutani Y \& Kudo T 2002 Inhibition of placental ornithine decarboxylase by DL-alpha-difluoromethyl ornithine causes fetal growth restriction in rat. Life Sciences 70 1395-1405. (https://doi.org/10.1016/s0024-3205(01)01510-7)

Jansson N, Pettersson J, Haafiz A, Ericsson A, Palmberg I, Tranberg M, Ganapathy V, Powell TL \& Jansson T 2006 Down-regulation of placental transport of amino acids precedes the development of intrauterine growth restriction in rats fed a low protein diet. Journal of Physiology 576 935-946. (https://doi.org/10.1113/jphysiol.2006.116509)

Jobgen WS, Ford SP, Jobgen SC, Feng CP, Hess BW, Nathanielsz PW, Li P \& Wu G 2008 Baggs ewes adapt to maternal undernutrition and maintain conceptus growth by maintaining fetal plasma concentrations of amino acids. Journal of Animal Science 86 820-826. (https://doi.org/10.2527/ jas.2007-0624)

Kavitha JV, Rosario FJ, Nijland MJ, McDonald TJ, Wu G, Kanai Y, Powell TL, Nathanielsz PW \& Jansson T 2014 Down-regulation of placental mTOR,
insulin/IGF-I signaling, and nutrient transporters in response to maternal nutrient restriction in the baboon. FASEB Journal 28 1294-1305. (https:// doi.org/10.1096/fj.13-242271)

Kim J, Song G, Wu G, Gao H, Johnson GA \& Bazer FW 2013 Arginine, leucine, and glutamine stimulate proliferation of porcine trophectoderm cells through the MTOR-RPS6K-RPS6-EIF4EBP1 signal transduction pathway. Biology of Reproduction 88 113. (https://doi.org/10.1095/ biolreprod.112.105080)

Kucharzewska P, Welch JE, Svensson KJ \& Belting M 2010 Ornithine decarboxylase and extracellular polyamines regulate microvascular sprouting and actin cytoskeleton dynamics in endothelial cells. Experimental Cell Research 316 2683-2691. (https://doi.org/10.1016/j. yexcr.2010.05.033)

Kulandavelu S, Qu D, Sunn N, Mu J, Rennie MY, Whiteley KJ, Walls JR, Bock NA, Sun JC, Covelli A, Sled JG \& AdamsonSL 2006 Embryonic and neonatal phenotyping of genetically engineered mice. ILAR Journal $\mathbf{4 7}$ 103-117. (https://doi.org/10.1093/ilar.47.2.103)

Kwon H, Ford SP, Bazer FW, Spencer TE, Nathanielsz PW, Nijland MJ, Hess BW \& Wu G 2004 Maternal nutrient restriction reduces concentrations of amino acids and polyamines in ovine maternal and fetal plasma and fetal fluids. Biology of Reproduction 71 901-908. (https://doi.org/10.1095/biolreprod.104.029645)

Lambo CA, Edwards AK, Bazer FW, Dunlap KA \& Satterfield MC 2020 Development of a surgical procedure for removal of a placentome from a pregnant ewe during gestation. Journal of Animal Science and Biotechnology 11 48. (https://doi.org/10.1186/s40104-020-00454-1)

Lassala A, Bazer FW, Cudd TA, Li P, Li X, Satterfield MC, Spencer TE \& Wu G 2009 Intravenous administration of L-citrulline to pregnant ewes is more effective than L-arginine for increasing arginine availability in the fetus. Journal of Nutrition 139 660-665. (https://doi.org/10.3945/ jn.108.102020)

Lassala A, Bazer FW, Cudd TA, Datta S, Keisler DH, Satterfield MC, Spencer TE \& Wu G 2010 Parenteral administration of L-arginine prevents fetal growth restriction in undernourished ewes. Journal of Nutrition 140 1242-1248. (https://doi.org/10.3945/jn.110.125658)

Laube G \& Bernstein HG 2017 Agmatine: multifunctional arginine metabolite and magic bullet in clinical neuroscience? Biochemical Journal 474 2619-2640. (https://doi.org/10.1042/BCJ20170007)

Laven R \& Peters A 2001 Gross Morphometry of the Bovine Placentome during Gestation. Reproduction in Domestic Animals 36 289-296. (https://doi.org/10.1046/j.1439-0531.2001.00297.x)

Lekatz LA, Ward MA, Borowicz PP, Taylor JB, Redmer DA, GrazulBilska AT, Reynolds LP, Caton JS \& Vonnahme KA 2010 Cotyledonary responses to maternal selenium and dietary restriction may influence alterations in fetal weight and fetal liver glycogen in sheep. Animal Reproduction Science 117 216-225. (https://doi.org/10.1016/j. anireprosci.2009.05.009)

Lekatz LA, Swanson TJ, Camacho LE, Van Emon ML, Schauer CS, Maddock Carlin KR, Hammer CJ, Lemley CO \& Vonnahme KA 2015 Maternal metabolizable protein restriction during late gestation on uterine and umbilical blood flows and maternal and fetal amino acid concentrations near term in sheep. Animal Reproduction Science 158 115-125. (https:// doi.org/10.1016/j.anireprosci.2015.05.009)

Lemley CO, Meyer AM, Camacho LE, Neville TL, Newman DJ, Caton JS \& Vonnahme KA 2012 Melatonin supplementation alters uteroplacental hemodynamics and fetal development in an ovine model of intrauterine growth restriction. American Journal of Physiology: Regulatory, Integrative and Comparative Physiology 302 R454-R467. (https://doi. org/10.1152/ajpregu.00407.2011)

Lenis YY, Elmetwally MA, Maldonado-Estrada JG \& Bazer FW 2017 Physiological importance of polyamines. Zygote 25 244-255. (https:// doi.org/10.1017/S0967199417000120)

Lenis YY, Johnson GA, Wang X, Tang WW, Dunlap KA, Satterfield MC, Wu G, Hansen TR \& Bazer FW 2018 Functional roles of ornithine decarboxylase and arginine decarboxylase during the peri-implantation period of pregnancy in sheep. Journal of Animal Science and Biotechnology 9 10. (https://doi.org/10.1186/s40104-017-0225-x)

Li X, Bazer FW, Johnson GA, Burghardt RC, Frank JW, Dai Z, Wang J, Wu Z, Shinzato I \& Wu G 2014 Dietary supplementation with L-arginine between days 14 and 25 of gestation enhances embryonic development and survival in gilts. Amino Acids 46 375-384. (https://doi.org/10.1007/ s00726-013-1626-6) 
Long NM, Vonnahme KA, Hess BW, Nathanielsz PW \& Ford SP 2009 Effects of early gestational undernutrition on fetal growth, organ development, and placentomal composition in the bovine. Journal of Animal Science 87 1950-1959. (https://doi.org/10.2527/jas.20081672)

Lopez-Garcia C, Lopez-Contreras AJ, Cremades A, Castells MT, Marin F, Schreiber F \& Penafiel R 2008 Molecular and morphological changes in placenta and embryo development associated with the inhibition of polyamine synthesis during midpregnancy in mice. Endocrinology 149 5012-5023. (https://doi.org/10.1210/en.2008-0084)

Malandro MS, Beveridge MJ, Kilberg MS \& Novak DA 1996 Effect of lowprotein diet-induced intrauterine growth retardation on rat placental amino acid transport. American Journal of Physiology 271 C295-C303. (https://doi.org/10.1152/ajpcell.1996.271.1.C295)

Mateo RD, Wu G, Bazer FW, Park JC, Shinzato I \& Kim SW 2007 Dietary L-arginine supplementation enhances the reproductive performance of gilts. Journal of Nutrition 137 652-656. (https://doi.org/10.1093/ jn/137.3.652)

McIntyre KR, Hayward CE, Sibley CP, Greenwood SL \& Dilworth MR 2019 Evidence of adaptation of maternofetal transport of glutamine relative to placental size in normal mice, and in those with fetal growth restriction. Journal of Physiology 597 4975-4990. (https://doi.org/10.1113/ JP278226)

McKnight SM, Simmons RM, Wu G \& Satterfield MC 2020 Maternal arginine supplementation enhances thermogenesis in the newborn lamb. Journal of Animal Science 98 skaa118. (https://doi.org/10.1093/ jas/skaa118)

Michael K, Ward BS \& Moore WM 1983 Relationship of fetal to placental size: the pig model. European Journal of Obstetrics, Gynecology, and Reproductive Biology 16 53-62. (https://doi.org/10.1016/00282243(83)90220-4)

Middleton P, Gomersall JC, Gould JF, Shepherd E, Olsen SF \& Makrides M 2018 Omega-3 fatty acid addition during pregnancy. Cochrane Database of Systematic Reviews 11 Cd003402. (https://doi.org/10.1002/14651858. CD003402.pub3)

Molteni RA, Stys SJ \& Battaglia FC 1978 Relationship of fetal and placental weight in human beings: fetal/placental weight ratios at various gestational ages and birth weight distributions. Journal of Reproductive Medicine 21 327-334.

Neri I, Monari F, Sgarbi L, Berardi A, Masellis G \& Facchinetti F 2010 L-arginine supplementation in women with chronic hypertension: impact on blood pressure and maternal and neonatal complications. Journal of Maternal-Fetal and Neonatal Medicine 23 1456-1460. (https:// doi.org/10.3109/14767051003677962)

Newnham JP, Kelly RW, Patterson L \& James I 1991 The influence of maternal undernutrition in ovine twin pregnancy on fetal growth and Doppler flow-velocity waveforms. Journal of Developmental Physiology 16 277-282.

Nickles KR, Hamer L, Coleman DN \& Relling AE 2019 Supplementation with eicosapentaenoic and docosahexaenoic acids in late gestation in ewes changes adipose tissue gene expression in the ewe and growth and plasma concentration of ghrelin in the offspring1. Journal of Animal Science 97 2631-2643. (https://doi.org/10.1093/jas/skz141)

Pantham P, Rosario FJ, Nijland M, Cheung A, Nathanielsz PW, Powell TL, Galan HL, Li C \& Jansson T 2015 Reduced placental amino acid transport in response to maternal nutrient restriction in the baboon. American Journal of Physiology: Regulatory, Integrative and Comparative Physiology 309 R740-R746. (https://doi.org/10.1152/ajpregu.00161.2015)

Pantham P, Rosario FJ, Weintraub ST, Nathanielsz PW, Powell TL, Li C \& Jansson T 2016 Down-regulation of placental transport of amino acids precedes the development of intrauterine growth restriction in maternal nutrient restricted baboons. Biology of Reproduction 95 98. (https://doi. org/10.1095/biolreprod.116.141085)

Pendeville H, Carpino N, Marine JC, Takahashi Y, Muller M, Martial JA \& Cleveland JL 2001 The ornithine decarboxylase gene is essential for cell survival during early murine development. Molecular and Cellular Biology 21 6549-6558. (https://doi.org/10.1128/MCB.21.19.65496558.2001)

Reynolds LP, Borowicz PP, Vonnahme KA, Johnson ML, Grazul-Bilska AT, Redmer DA \& Caton JS 2005a Placental angiogenesis in sheep models of compromised pregnancy. Journal of Physiology 565 43-58. (https:// doi.org/10.1113/jphysiol.2004.081745)
Reynolds LP, Borowicz PP, Vonnahme KA, Johnson ML, Grazul-Bilska AT, Wallace JM, Caton JS \& Redmer DA 2005b Animal models of placental angiogenesis. Placenta 26 689-708. (https://doi.org/10.1016/j. placenta.2004.11.010)

Reynolds LP, Caton JS, Redmer DA, Grazul-Bilska AT, Vonnahme KA, Borowicz PP, Luther JS, Wallace JM, Wu G \& Spencer TE 2006 Evidence for altered placental blood flow and vascularity in compromised pregnancies. Journal of Physiology 572 51-58. (https://doi.org/10.1113/ jphysiol.2005.104430)

Roberts VH, Lo JO, Salati JA, Lewandowski KS, Lindner JR, Morgan TK \& Frias AE 2016 Quantitative assessment of placental perfusion by contrast-enhanced ultrasound in macaques and human subjects. American Journal of Obstetrics and Gynecology 214 369.e1-369.e8. (https://doi.org/10.1016/j.ajog.2016.01.001)

Roberts VHJ, Lo JO, Lewandowski KS, Blundell P, Grove KL, Kroenke CD, Sullivan EL, Roberts Jr CT \& Frias AE 2018 Adverse placental perfusion and pregnancy outcomes in a new nonhuman primate model of gestational protein restriction. Reproductive Sciences 25 110-119. (https://doi.org/10.1177/1933719117704907)

Roos S, Jansson N, Palmberg I, Säljö K, Powell TL \& Jansson T 2007 Mammalian target of rapamycin in the human placenta regulates leucine transport and is down-regulated in restricted fetal growth. Journal of Physiology $\mathbf{5 8 2}$ 449-459. (https://doi.org/10.1113/ jphysiol.2007.129676)

Rosa Velazquez M, Batistel F, Pinos Rodriguez JM \& Relling AE 2020 Effects of maternal dietary omega-3 polyunsaturated fatty acids and methionine during late gestation on fetal growth, DNA methylation, and mRNA relative expression of genes associated with the inflammatory response, lipid metabolism and DNA methylation in placenta and offspring's liver in sheep. Journal of Animal Science and Biotechnology 11 111. (https:// doi.org/10.1186/s40104-020-00513-7)

Saccone G, Berghella V, Maruotti GM, Sarno L \& Martinelli P 2015 Omega-3 supplementation during pregnancy to prevent recurrent intrauterine growth restriction: systematic review and meta-analysis of randomized controlled trials. Ultrasound in Obstetrics and Gynecology 46 659-664. (https://doi.org/10.1002/uog.14910)

Sandoval C, Lambo CA, Beason K, Dunlap KA \& Satterfield MC 2020 Effect of maternal nutrient restriction on skeletal muscle mass and associated molecular pathways in SGA and non-SGA sheep fetuses. Domestic Animal Endocrinology 72 106443. (https://doi.org/10.1016/j. domaniend.2020.106443)

Satterfield MC, Bazer FW, Spencer TE \& Wu G 2010a Sildenafil citrate treatment enhances amino acid availability in the conceptus and fetal growth in an ovine model of intrauterine growth restriction. Journal of Nutrition 140 251-258. (https://doi.org/10.3945/jn.109.114678)

Satterfield MC, Gao H, Li X, Wu G, Johnson GA, Spencer TE \& Bazer FW $2010 b$ Select nutrients and their associated transporters are increased in the ovine uterus following early progesterone administration. Biology of Reproduction $\mathbf{8 2}$ 224-231. (https://doi.org/10.1095/ biolreprod.109.076729)

Satterfield MC, Dunlap KA, Keisler DH, Bazer FW \& Wu G 2013 Arginine nutrition and fetal brown adipose tissue development in nutrientrestricted sheep. Amino Acids 45 489-499. (https://doi.org/10.1007/ s00726-011-1168-8)

Sibley CP, Brownbill P, Dilworth M \& Glazier JD 2010 Review: adaptation in placental nutrient supply to meet fetal growth demand: implications for programming. Placenta 31 S70-S74. (https://doi.org/10.1016/j. placenta.2009.12.020)

Staff AC, Berge L, Haugen G, Lorentzen B, Mikkelsen B \& Henriksen T 2004 Dietary supplementation with L-arginine or placebo in women with pre-eclampsia. Acta Obstetricia et Gynecologica Scandinavica 83 103-107.

Steinhauser CB, Askelson K, Lambo CA, Hobbs KC, Bazer FW \& Satterfield MC 2021 Lipid metabolism is altered in maternal, placental, and fetal tissues of ewes with small for gestational age fetusesdagger. Biology of Reproduction 104 170-180 (https://doi.org/10.1093/biolre/ ioaa180).

Thompson RS \& Trudinger BJ 1990 Doppler waveform pulsatility index and resistance, pressure and flow in the umbilical placental circulation: an investigation using a mathematical model. Ultrasound in Medicine and Biology 16 449-458. (https://doi.org/10.1016/03015629(90)90167-b) 
Vadillo-Ortega F, Perichart-Perera O, Espino S, Avila-Vergara MA, Ibarra I, Ahued R, Godines M, Parry S, Macones G \& Strauss JF 2011 Effect of supplementation during pregnancy with L-arginine and antioxidant vitamins in medical food on pre-eclampsia in high risk population: randomised controlled trial. BMJ 342 d2901. (https://doi.org/10.1136/bmj.d2901)

van Wagenen G \& Catchpole HR 1965 Growth of the fetus and placenta of the monkey (Macaca mulatta). American Journal of Physical Anthropology 23 22-33. (https://doi.org/10.1002/ajpa.1330230117)

Wang CX, Chen F, Zhang WF, Zhang SH, Shi K, Song HQ, Wang YJ, Kim SW \& Guan WT 2018 Leucine promotes the growth of fetal pigs by increasing protein synthesis through the mTOR signaling pathway in longissimus dorsi muscle at late gestation. Journal of Agricultural and Food Chemistry 66 3840-3849. (https://doi.org/10.1021/acs. jafc.8b00330)

Weckman AM, McDonald CR, Baxter JB, Fawzi WW, Conroy AL \& Kain KC 2019 Perspective: L-arginine and L-citrulline supplementation in pregnancy: a potential strategy to improve birth outcomes in lowresource settings. Advances in Nutrition 10 765-777. (https://doi. org/10.1093/advances/nmz015)

WHO 2018 Global Nutrition Report. (https://globalnutritionreport.org/ reports/global-nutrition-report-2018/

Wu G, Knabe DA \& Kim SW 2004 Arginine nutrition in neonatal pigs. Journal of Nutrition 134 (Supplement) 2783S-2790S. (https://doi. org/10.1093/jn/134.10.2783S)

Wu G, Bazer FW, Cudd TA, Jobgen WS, Kim SW, Lassala A, Li P, Matis JH, Meininger CJ \& Spencer TE 2007 Pharmacokinetics and safety of arginine supplementation in animals. Journal of Nutrition 137 (Supplement 2) 1673S-1680S. (https://doi.org/10.1093/jn/137.6.1673S)

Wu G, Bazer FW, Davis TA, Kim SW, Li P, Marc Rhoads J, Carey Satterfield M, Smith SB, Spencer TE \& Yin Y 2009 Arginine metabolism and nutrition in growth, health and disease. Amino Acids 37 153-168. (https://doi.org/10.1007/s00726-008-0210-y)

Wu G, Bazer FW, Burghardt RC, Johnson GA, Kim SW, Knabe DA, Li P, Li X, McKnight JR, Satterfield MC et al. 2011 Proline and hydroxyproline metabolism: implications for animal and human nutrition. Amino Acids 40 1053-1063. (https://doi.org/10.1007/s00726-010-0715-z)

Wu G, Bazer FW, Johnson GA, Herring C, Seo H, Dai Z, Wang J, Wu Z \& Wang X 2017 Functional amino acids in the development of the pig placenta. Molecular Reproduction and Development 84 870-882. (https://doi.org/10.1002/mrd.22809)

Zhang H, Sun L, Wang Z, Deng M, Nie H, Zhang G, Ma T \& Wang F 2016 $\mathrm{N}$-carbamylglutamate and L-arginine improved maternal and placental development in underfed ewes. Reproduction 151 623-635. (https://doi. org/10.1530/REP-16-0067)

Received 27 April 2021

First decision 3 June 2021

Revised manuscript received 11 June 2021

Accepted 27 July 2021 